\title{
Chapter 33 \\ Social Exclusion in Older-Age and the European Pillar of Social Rights
}

\author{
Maciej Kucharczyk
}

\subsection{Introduction}

Framed by an understanding of the role of the European Union in member states' social policy making, this chapter has a focus on analysing the potential of the European Pillar of Social Rights to address social exclusion of older people, the challenges that might impede its efforts, and the measures necessary to overcome such challenges.

To understand the place of European Pillar of Social Rights (the Pillar) in the EU policy context and its most likely impact on policy making, it is helpful to consider the evolution of the EU's evolving role in shaping national social policies since the beginning of European integration in the period that followed the Second World War. Already the Treaty of Rome (1957), which established the original European Economic Community (EEC), today's European Union (EU), contained first social policy measures, such as the free movement of labour and the provision of equal pay for men and women (Scharf 2010). These measures emphasised solidarity as one of the founding principles of European integration. EEC member states considered solidarity to be an intrinsic element of their common vision for development in the post-war period, combining economic growth with high living standards and good working conditions. However, in the 1960s and 1970s progress on harmonising EEC member states' social policies was limited to reaching agreement on broad policy goals (Scharf 2010). This already modest approach was challenged even further by the growing influence of neo-liberal economic and social policy thinking at the beginning of the 1980s. Eventually, "the resulting policy blockage was overcome by the Single European Act (1986), which confirmed the need to 'improve the Community's economic and social situation by extending common policies and pursuing new objectives'."

M. Kucharczyk ( $\triangle)$

AGE Platform Europe, Brussles, Belgium

e-mail: maciej.kucharczyk@age-platform.eu 
With the Treaty of Maastricht (1992), the name of the European Economic Community was changed to the European Community. Omitting the term "economic" was all but semantic - it indicated member states' willingness to pursue integration beyond its purely economic objectives. Article 2 of the Treaty of Maastricht emphasised a high level of employment and of social protection, economic and social cohesion and solidarity. In 2000, the supra-national coordination received a new impetus, including in the social field, with the introduction of the Open Method of Coordination (OMC). The OMC was intended as a method of soft governance, aiming to spread best practice and achieve convergence towards EU goals in those policy areas which fall under shared or supporting competences of member states, such as social inclusion, health, education, youth or vocational training. Applied to the areas of social inclusion, health care and long-term care and pensions (Social OMC), the new framework provided further opportunity at European level to address social exclusion in older-age. Member states had the opportunity to exchange policy ideas and mutually learn from one another in relation to social policies. The aim was to strengthen well-being and cohesion in ageing societies, specifically in terms of the affordability, availability and quality of health and long-term care services underpinning older people's capacity to participate fully in society; and adequate and sustainable pension systems determining older people's income and de facto their social inclusion.

In 2009, the Treaty of Lisbon introduced additional measures with a social policy focus, including the social market, human dignity, justice and social integration, and gender equality. The EU was charged with a mission to contribute to overall sustainable development in the world, based on solidarity and reciprocal respect, where trade is simultaneously both free and just (Stjernø 2011). Article 151 of the Treaty on the Functioning of the European Union (TFEU) details the EU's key social policy objectives: promoting employment, improving working and living conditions, equal treatment of workers, adequate social protection according to need, social dialogue, developing human resources aimed at achieving a high and sustainable level of employment, as well as combating exclusion. In addition, Article 6 of the Treaty on European Union (TEU) gives binding force to the social rights in the EU Charter of Fundamental Rights. Consequently, the Charter consolidates all the fundamental rights applicable at the EU level. Finally, Art. 9 of the Lisbon Treaty, the so-called "horizontal social clause" proclaims that the Union has to take into account [...] the guarantee of adequate social protection [...] when implementing new policies.

Notwithstanding these attempts, over the decades, the EU action in the social field has remained limited to supporting member states in the organisation and implementation of national policies. It was only in the aftermath of the global financial and economic crisis of 2008 that a new approach emerged. Under public pressure to recognise the EU's responsibility to address the social consequences of the crisis, national governments and European institutions recognised the need to rebalance EU action. The objective of further economic integration was linked closer to progress towards greater social cohesion and equality. A new comprehensive vision for Europe to achieve "smart, sustainable and inclusive growth" was proposed in the form of the Europe 2020 Strategy. Launched in 2010, the Strategy set five 
"headline" targets to achieve within the next decade, including ones to lift 20 million people out of poverty, reduce rates of early school leaving to below $10 \%$, and ensure participation of $75 \%$ of 20-64 year-olds in the labour market. Yet, once again, the attempt to add a strong social dimension to EU policy making failed. The Europe 2020 Strategy has largely failed in achieving its social goals, most evidently in terms of eradicating poverty. The Strategy's fate was sealed before even reaching 2020 and de facto paved the way to the proclamation of the European Pillar of Social Rights.

\subsection{European Pillar of Social Rights}

The European Pillar of Social Rights was proclaimed jointly by the European Parliament, the European Council and the European Commission at the Social Summit for Fair Jobs and Growth on $17^{\text {th }}$ November 2017 in Gothenburg. The proclamation was more than symbolic. After years of loose and patchy initiatives in the social field, the EU institutions and member states agreed on a common set of social rights and principles to improve the lives of Europeans through greater equality, inclusion and well-being. This is emphasised in the Pillar's Preamble, which states that "The Union shall combat social exclusion and discrimination, promote social justice and protection, equality between women and men, solidarity between generations and protection of the rights of the child." Built upon 20 principles and rights clustered in three categories of "equal opportunities and access to the labour market", "fair working conditions" and "social protection and inclusion", the Pillar offers a broad policy agenda addressing various social needs.

The proposed rights-based approach makes the Pillar "potentially more powerful than harmonisation of overly divergent policy instruments or attempts at convergence on overly vague objectives" (Cantillon 2019). To be implemented properly, the Pillar could follow the examples of the European Charter of Social Rights or the United Nations' system of human-rights treaty bodies. The two frameworks are articulated around rights, promoting them through indicators and monitoring, establishing action plans and checking if progress is being made towards agreed benchmarks.

However, there remain uncertainties around how national governments and European institutions will fulfil their joint commitment. The Pillar's preamble explicitly states that dedicated measures or legislation must be adopted at the appropriate level for the 20 rights and principles to be legally enforceable. This means that while the EU institutions can propose initiatives and actions, either through legislation or soft policy measures, the responsibility to deliver on the Pillar lies principally in the hands of member states. However, member states can refuse to implement the proposed initiative evoking the lack of dedicated measures or legislation at the national level. Moreover, the implementation of the Pillar is supposed to take account of member states' different socio-economic environments and respect the fundamental principles of national social security systems. 
At the same time, expectations of the Pillar are high. Stakeholders, including civil society, hope that the political engagement made by member states in Gothenburg will have a positive impact on improving people's daily realities. This should happen through rebalancing social versus economic considerations in national and EU policy making. According to Garben (2019), the Pillar:

\footnotetext{
'...has put a surprising social spin on the Better Regulation Agenda that was threatening to erode the social acquis, it has rekindled the EU's relationship with the International Labour Organization and Council of Europe, and it helps rebalance the EU's output by reviving the use of the Treaty's Social Title'.
}

While it is too early to draw definitive conclusions, one can at least welcome the Pillar's first concrete achievement - the proposal for an EU directive on carers' leave to support informal carers. However, even this very first attempt to put the Pillar's principles into practice to strengthen EU social acquis is challenged by some member states. An open question remains as to what extent future initiatives of the Pillar will effectively combat social exclusion and discrimination, or consider the intersection of inequalities and multiple discriminations, such as, for example, of older women or older persons with disabilities. Moreover, the Pillar's reference to non-discrimination made under Chapter I, referring to "Equal opportunities and access to the labour market", may impede its efforts to addresses the causes of social exclusion beyond the employment-related perspective and working-age population. Such a limited approach to ageing policy may distract attention from various forms of exclusion in later life that reach beyond work and employment [see also Walsh et al. this volume]. This would include, for example, attention focused on disadvantages arising from age discrimination, limited material resources, lack of access to services, or one's place of residence (Scharf et al. 2004).

In terms of governance, there is no clear vision of how the Pillar will be implemented or of how it will be embedded in the EU's overall economic agenda. The absence of a post-Europe 2020 strategy with a social component puts additional risk on the policy impact of the Pillar. Neither legally binding, nor underpinned by sanctions for no-action, the Pillar's long-term implementation is thus unclear. Notwithstanding several references to the Pillar in the political guidelines of the new Commission President, Ursula von der Leyen, who included an explicit call for an implementation plan, no-one can predict the scope of future initiatives that the Commission will propose to fulfil the engagements of the Pillar. The ultimate impact of the Gothenburg 2017 social summit to make the EU agenda more socially oriented remains to be demonstrated.

\subsection{The Pillar's Relevance to Addressing Social Exclusion of Older People}

Several of the Pillar's rights and principles are relevant to older people on a general level, in relation to social protection and inclusion. They also apply in more specific ways, in terms of the adequacy of old-age income and pensions, facilitating the 
transition from work into retirement, or guaranteeing quality and affordable longterm care. However, the Pillar's ability to address social exclusion in older-age and its ultimate impact on policies depends on the level of understanding of the multidimensional nature of exclusion (e.g. Scharf and Keating 2012). This in turn undermines the capacity of policy makers to develop and implement policies which will reduce adequately social exclusion in later life (Walsh et al. 2017).

\subsubsection{Principles Relating to Specific Forms of Old-Age Exclusion}

A combination of factors such as low income, poor health, age and/or gender-based discrimination, reduced physical or mental capacity, unemployment, isolation, abuse, and limited access to services can all play a part in increasing the risk of poverty and social exclusion as people age (Walsh et al. 2017). The following principles of the Pillar are particularly relevant to address the multidimensionality of exclusion in later life (i.e. economic, social relations, services, community/spatial, civic and symbolic exclusion):

- Principle 1: The right to education, training and lifelong learning when applied to persons of all ages - when it is understood that this is a precondition for maintaining employability, social inclusion and health across the whole life span.

- Principle 3: The right to equal opportunities regardless of gender, racial or ethnic origin, religion or belief, disability, age or sexual orientation in respect to employment, social protection, education and goods and services - to foster cohesion in society where all population and age groups participate on an equal basis.

- Principle 4: The right to active support to employment - key to older jobseekers, who are often left out of active labour market policies that should support their (re)integration within the labour market.

- Principle 5: The right to secure and adaptable employment - indispensable to adapt labour markets and working conditions to provide for the socio-economic needs of an ageing population, including those workers who either need or want to continue working at an older-age (e.g. due to inadequate retirement savings, because of job satisfaction or the need for social interaction).

- Principle 9: The right to work-life balance which took the most concrete form of the European Directive including a paid leave (equivalent to sick leave) to care for dependent relatives - when adequately transposed and implemented at national level, the Directive will enable a more equitable sharing of child care and introduce remunerated carers' leave; this will be a major achievement for many women who must withdraw from the labour market to take on informal care responsibilities.

- Principle 12: The right to social protection for both workers and self-employed people regardless of the type and duration of their employment relationship - key to extending the benefits of social protection to everyone in a constantly changing labour market context (e.g. digital platform workers). 
- Principle 14: The right to minimum income "at all stages of life" recognises the challenge of adequacy of minimum income schemes beyond the working-age population. An additional reference made to "effective access to enabling goods and services" indicates that non-monetary aspects, which are vital for many older persons to live in dignity, should be taken into consideration.

- Principle 15: The right to old-age income and pensions with the stated aims of "living in dignity" and "equal opportunities of women and men to acquire pension rights" - echoes the challenge of eroding older people's incomes due to declining replacement rates, the shift from pay-as-you-go to funded pension schemes or the persisting gender pension gap.

- Principle 16: The right to health care, referring both to preventive and curative health as well as affordability and quality - the features are indispensable for enabling not only longer, but also healthier lives and equity in health outcomes.

- Principle 17: The right to inclusion of persons with disabilities including adequate income and access to services with an objective to enable them "participate in society" - this broad approach recognises the need to extend social inclusion and participation beyond merely the labour market.

- Principle 18: The right to "affordable long-term care services of good quality, in particular home care and community-based services" - this is a first such implicit reference made at EU level to the challenge of adequate support and assistance to older persons; this also reflects the provisions of Article 25 of the Charter of Fundamental Rights of the European Union, recognising "the rights of the elderly to lead a life of dignity and independence and to participate in social and cultural life".

- Principle 20: The right "to access essential services of good quality, including water, sanitation, energy, transport, financial services and digital communications including support for access to such services" - provides a comprehensive approach to social inclusion beyond solely income-related aspects.

\subsubsection{Example of the Pillar's Challenges to Address the Economic Risk of Exclusion in Later Life}

In relation to economic exclusion, the right to "Minimum Income" (Principle 14) provides space for new EU policy action. However, first, it requires further clarification of what income adequacy should entail. One can hope that the reference made to "effective access to enabling goods and services" translates into a willingness to address and cover by minimum income schemes access to goods and services that reach beyond individuals' basic and monetary-related needs. For example, promoting and encouraging member states through the Pillar to develop and use national baskets of goods and services, based on a common reference budget methodology, would be helpful. Reference budgets are priced baskets of goods and services that represent a given living standard (Bradshaw 1993). While such budgets are widespread and increasingly applied across European countries, there are considerable 
differences in their methodologies and the ways in which they are implemented. The EU and member states use the at-risk-of-poverty-threshold (ARPT) - calculated as a percentage $(60 \%)$ of median equivalent household income - as a benchmark against which an adequate minimum income can be assessed. However, the method ignores that the opportunities to participate fully in society are also determined by other structural and individual factors, such as the availability and accessibility of public goods and services and the extent to which human needs of health and autonomy are fulfilled (Storms et al. 2014). Therefore, the Pillar provides the EU with further responsibility to promote an adequate income across the life span and should focus more on the respective needs of different age and population groups. In regard to older persons, reference budgets should be broken down by gender and by age groups $(65-75,75-85$ and over 85 years) in order to reflect older people's evolving needs as they age, including, for example, the higher cost of longterm care for the oldest old. Reference budgets could be part of the EU's further reflection and action on adequacy of minimum income schemes. Although not meant to be used in a prescriptive way, such as determining what people should or should not do, reference budgets provide information about the financial conditions necessary to ensure a person's full social participation. Therefore, reference budgets could be useful when evaluating the adequacy of national minimum income benefits and for guiding EU and national policy choices in social protection and social inclusion policies (Storms et al. 2014).

The right to "old-age income and pensions" (Principle 15) suggests that "workers and the self-employed in retirement have the right to a pension commensurate to their contributions and ensuring an adequate income". This formulation broadens the scope and goes beyond existing acquis by recognising the right of self-employed people to access social protection, even though the reference to individual contributions reflects the general tendency in pension reforms across EU countries to introduce an ever-closer link between earnings/contributions and benefits [see Ogg this section]. On a more positive note, the mention of equal opportunities for women and men to acquire pension rights echoes the evidence concerning the persisting gender pension gap and the European Commission's efforts to address this phenomenon in recent years. Equally important, the notion that "everyone in old-age has the right to resources that ensure living in dignity" represents another step forward in debates about the adequacy of pensions and old-age income for all. It encompasses not only people who can accrue pension rights through employment, but also all those who are permanently or temporarily unable to work due to disability and people who for justifiable reasons are no longer available to work, or have shorter or interrupted working carriers and therefore are unable to build adequate pension rights.

\subsection{The Pillar to Socialise the European Semester}

The key EU policy instrument to guide national macroeconomic and structural reforms, the European Semester (Semester), remains largely disconnected from the reflection on social aspects and their place in the overall economic growth 
paradigm. Actors at the national and EU levels, such as trade unions, civil society and academia, argue that the Pillar, if meant to underpin the EU's social agenda, should steer member states' policies through the Semester, to ensure a closer connection between the two processes (e.g. Vanhercke et al. 2017). Arrangements for implementing the Pillar through the Semester were already specified by the European Commission in the Annual Growth Survey 2018 and the Draft Joint Employment Report 2018. However, an open question remains as to what extent the Pillar's principles and rights will be considered through the implementation of the Semester at national level (i.e. the National Reform Programmes). The main challenge faced by the EU and member states is the ability to ensure consistency between economic, employment and financial policies with a view to strengthening the social dimension. Two years after the proclamation of the Pillar, it seems that the Semester has been paying more attention to social issues, including those relevant for older people, such as life-long learning, employment of older workers or quality long-term care systems. In its annual assessment of the Semester in 2018, AGE Platform Europe (AGE) considered the impact of the Semester's implementation on the social realities of older persons (Age Platform 2018). According to AGE, the adequacy of pensions had been addressed by the European Commission in its recommendations to those member states where the level of pensions is dramatically low. However, AGE members regret the lack of further focus on the most vulnerable groups of pensioners, such as older women, the very old or older persons with health issues. Moreover, other barriers that prevent older people from exercising their social rights, including those listed in the Pillar, are not addressed in the Semester. This includes barriers such as the investment gap in long-term care, the lack of accessibility of physical and digital environments, or the difficult situation of older jobseekers. Instead of emphasising its potential opportunities, population ageing remains perceived by many policy makers more as a burden to the public purse, which needs to be contained, than as an achievement and opportunity.

\subsection{Conclusion}

Considering the multiple crises that Europe has been facing over the last decade and growing public scepticism towards the European project, the proclamation of the European Pillar of Social Rights was a first attempt by EU institutions and member states to create conditions for greater fairness and solidarity at both the macro level (among countries and regions) and at the grass-roots level (among age and population groups and individuals themselves). The Pillar recognised the key role played by social rights in empowering all population and age groups as equal holders of social and, broadly, human rights. Consequently, the Pillar has the potential to improve not only daily realities of Europeans, but, equally importantly, to improve their perception of the EU as such. Eventually, this could have a positive spill-over effect beyond the strictly socio-economic sphere by helping to (re)adhere European people back to the European values and the common integration project. 
Since the Pillar does not confer new competences or tasks upon the European Union, the EU does not have an enlarged competence in relation to the design of pension systems. Nor are the 20 rights and principles directly enforceable without implementing measures. Therefore, the ultimate impact of the Pillar will depend on the political will of both EU institutions and member states to develop concrete policy actions to implement the Pillar. In the long run, the European Court of Justice could refer to the Pillar when interpreting EU law, and de facto exercise pressure on policy makers to implement measures addressing the social needs of European people, including of those in later life.

Political will, commitment and accountability are all and equally needed for the Pillar to succeed and to avoid mistakes of the past, such as the lack of progress on the Europe 2020 Strategy's social headline targets (e.g. on poverty reduction). There remains a question concerning how the Pillar's implementation will inform the post-Europe 2020 strategy and how the latter will articulate and align its policy objectives with the Agenda 2030 and the Sustainable Development Goals. Stakeholder involvement, including involvement of civil society, will be another key element to enable the EU to steer national policies using the Pillar's principles and rights. At a broader level, further reflection is needed on other political processes that can underpin the EU's social dimension provided by the Pillar. Other policy standards, such as the International Labour Organisation's core convention and the Council of Europe's Social Charter should be used as inspiration.

Europe is still suffering the consequences of the 2008 economic crisis. Older people have not been spared in this process: the gender pension gap is close to $40 \%$ and poverty persists among many older women, the oldest old, those who were not able to build an adequate pension, or older persons whose income has eroded over time, in particular due to the growing costs of health care. The individualisation of old-age dependency risks, with increased out-of-pocket payments for health care, is undermining the universal character of health care that is a part of the European social welfare model. Pension reforms that delay the age at which people become eligible to receive their pensions are hitting vulnerable groups, such as the $48 \%$ of people aged between 55 and 64 years who are not in employment, not yet of pensionable age and who have very low prospects of finding a job.

Most of the Pillar's 20 principles and rights are directly relevant to older people and, therefore, of key importance. The ultimate impact they will have on the improvement of older people's social realities will depend on how comprehensive and mutually reinforcing the future policy actions proposed under the Pillar will be. Their overarching objective should be to address the multidimensionality of exclusion in later life from a rights-based perspective, for example by enhancing the rights to quality and affordable health and long-term care, to adequate pensions to live in dignity, to age-friendly working conditions and an inclusive labour market, or to access goods and services. To do so, member states and EU institutions must align any forthcoming Pillar proposals with Article 25 of the European Charter of Fundamental Rights, thereby acknowledging the right of older persons to live independently and in dignity. 


\section{Author's Postscript}

Beyond the immediate challenges of saving lives and keeping healthcare systems functioning, the COVID-19 crisis has triggered an unprecedented shift in national and European policies. In this context, the Pillar of Social Rights acquires new importance; the full implementation of all its principles is more indispensable than ever and should underpin the recovery strategies that Member States and the EU put in place. With regard to older people, the Pillar's various principles are particularly important during and after the pandemic. These include universal health and longterm care services, and ensuring adequate social protection for all, including minimum safety nets or inclusive employment policies. The Pillar, together with the EU's environmental objectives and the UN's Sustainable Development Goals, should guide recovery strategies based on human rights, social inclusion and solidarity between all age and population groups.

\section{References}

AGE Platform Europe. (2018). Assessment of the European Semester 2018, with country perspectives from France, Italy, Malta and Spain. Brussels: Age Platform Europe. Available at: https:// www.age-platform.eu/sites/default/files/AGE_Position_on_EUSemester2018.pdf

Bradshaw, J. (Ed.). (1993). Budget standards for the United Kingdom. Aldershot: Avebury.

Cantillon, B. (2019). The European Pillar of Social Rights: ten arguments for prioritising principle 14 on minimum incomes, Working Paper 19.02. Antwerp: Herman Deleeck Centre for Social Policy. Available at: http://www.centrumvoorsociaalbeleid.be/sites/default/files/ CSBWorkingPaper1902.pdf

Garben, S. (2019). The European pillar of social rights: An assessment of its meaning and significance. Cambridge Yearbook of European Legal Studies, 21, 101-127.

Scharf, T. (2010). Social policies for ageing societies: Perspectives from Europe. In D. Dannefer \& C. Phillipson (Eds.), The SAGE handbook of social gerontology (pp. 497-512). London/ New York: Sage.

Scharf, T., \& Keating, N. (2012). Social exclusion in later life: A global challenge. In T. Scharf $\&$ N. Keating (Eds.), From exclusion to inclusion in old age: A global challenge (pp. 1-16). Bristol: Policy Press.

Scharf, T., Phillipson, C., \& Smith, A. E. (2004). Poverty and social exclusion: Growing older in deprived urban neighbourhoods. In A. Walker \& C. H. Hennessy (Eds.), Growing older: Quality of life in old age (pp. 81-106). Maidenhead: Open University Press.

Stjern $\varnothing$, S. (2011). The idea of solidarity in Europe. European Journal of Social Law, 3, 170-173.

Storms, B., Kurcharczyk, M., Leydet, L., McKinney, C., \& Perek-Bialas, J. (2014). What should an adequate old-age income entail to live in dignity? Learnings from France, Ireland and Poland. Brussels: Age Platform Europe. Available at: https://www.age-platform.eu/sites/default/files/ AGE_EMIN_publication_Dec2014_EN.pdf.

Vanhercke, B., Natali, D., \& Bouget, D. (2017). Social policy in the European Union: State of play 2016. Brussels: European Trade Union Institute. Available at: https://www.etui.org/fr/content/ download/33096/306832/file/17+Social+policy+in+EU+2017+OSE+Web+version.pdf

Walsh, K., Scharf, T., \& Keating, N. (2017). Social exclusion of older persons: A scoping review and conceptual framework. European Journal of Ageing, 14(1), 81-98. 
Open Access This chapter is licensed under the terms of the Creative Commons Attribution 4.0 International License (http://creativecommons.org/licenses/by/4.0/), which permits use, sharing, adaptation, distribution and reproduction in any medium or format, as long as you give appropriate credit to the original author(s) and the source, provide a link to the Creative Commons license and indicate if changes were made.

The images or other third party material in this chapter are included in the chapter's Creative Commons license, unless indicated otherwise in a credit line to the material. If material is not included in the chapter's Creative Commons license and your intended use is not permitted by statutory regulation or exceeds the permitted use, you will need to obtain permission directly from the copyright holder. 